\title{
WEWENANG DAN TANGGUNG JAWAB HUKUM KURATOR ATAS KESALAHAN ATAU KELALAIANNYA MENGAKIBATKAN KERUGIAN BAGI DEBITOR DALAM PROSES HUKUM PENGURUSAN DAN PEMBERESAN HARTA PAILIT
}

\author{
Serlika Aprita \\ Fakultas Hukum Universitas Muhammadiyah Palembang \\ E-mail: 5312lika@gmail.com
}

\begin{abstract}
In general, the monetary crisis that hit a country gave an unfavorable influence on the economic life of the country concerned and caused great difficulties in the business community to continue its activities. The ability of the business world to develop its business is very disturbed, even to maintain the continuity of its business activities is also not easy. It was decided that a debtor becomes a bankrupt debtor by the Commercial Court, it will cause legal consequences for the debtor and his assets. In connection with the loss of the right to control and manage the assets of the debtor, the curator has the authority to administer and deposit bankrupt assets. However, in its implementation, the curator has done a lot of mistakes and negligence in carrying out his duties, as found in various case examples, so the debtor must be responsible for errors and omissions. The existence of legal ratios as well as the form and mechanism of curatory legal responsibility has been regulated in Law Number 37 of 2004 based on the theory of legal responsibility and legal protection theory and the opinions of bankruptcy law experts are the main basis for curators to be responsible for their errors or omissions. It is expected that the curator in carrying out his duties to manage and deposit bankrupt debtors' assets can maximally increase the value of bankrupt assets in the interest of creditors.
\end{abstract}

Keywords: Debtors, Creditors, Curators, Legal Responsibilities, Errors or Negligence

\begin{abstract}
ABSTRAK
Pada umumnya krisis moneter yang melanda suatu negara memberi pengaruh yang tidak menguntungkan terhadap kehidupan perekonomian negara yang bersangkutan dan menimbulkan kesulitan besar di kalangan dunia usaha untuk meneruskan kegiatannya. Kemampuan dunia usaha dalam mengembangkan usahanya sangat terganggu, bahkan untuk mempertahankan kelangsungan kegiatan usahanya juga tidak mudah.Dengan diputuskannya seorang debitor menjadi debitor pailit oleh Pengadilan Niaga, maka akan menimbulkan akibat hukum terhadap debitor dan hartanya. Sehubungan dengan hilangnya hak untuk menguasai dan mengurus kekayaan debitor maka kuratornya yang berwenang melakukan pengurusan dan pemberesan harta pailit.Namun pada penerapannya kurator banyak melakukakan kesalahan dan kelalaiannya dalam menjalankan tugasnya, hal ini sebagaimana ditemukan dalam berbagai contoh kasus,sehingga debitor harus bertanggung jawab atas adanya kesalahan dan kelalainnya. Adanya rasio hukum serta bentuk dan mekanisme tanggung jawab hukum kuratoryang telah diatur dalam Undang-Undang Nomor 37 Tahun 2004 dengan berpedoman kepada teori tanggung jawab hukum dan teori perlindungan hukum dan pendapat para ahli hukum kepailitan menjadi dasar utama kurator untuk bertanggung jawab atas kesalahan atau kelalaiannya. Diharapkan kurator dalam menjalankan tugasnya melakukan pengurusan dan pemberesan harta debitor pailit dapat semaksimal mungkin meningkatkan nilai harta pailit demi kepentingan para kreditor.
\end{abstract}

Kata Kunci:Debitor, Kreditor, Kurator,TanggungJawab Hukum,Kesalahan atau Kelalaian. 


\section{PENDAHULUAN}

\section{A. Latar Belakang}

Dalam kegiatan usaha pada era global seperti sekarang ini pada kenyataannya tidak mungkin terisolir dari masalahmasalah lain.Suatu perusahaan yang dinyatakan pailit pada saat ini akan mempunyai imbas dan pengaruh buruk bukan hanya kepada perusahaan itu saja melainkan berakibat global.Pada umumnya krisis moneter yang melanda suatu negara memberi pengaruh yang tidak menguntungkan terhadap kehidupan perekonomian negara yang bersangkutan dan menimbulkan kesulitan besar di kalangan dunia usaha untuk meneruskan kegiatannya. Kemampuan dunia usaha dalam mengembangkan usahanya sangat terganggu, bahkan untuk mempertahankan kelangsungan kegiatan usahanya juga tidak mudah. ${ }^{1}$ Lebih jauh lagi, gejolak tersebut juga telah memberi pengaruh besar terhadap kemampuan dunia usaha untuk memenuhi kewajiban pembayaran utang mereka kepada kreditor. Keadaan ini pada gilirannya telah melahirkan akibat yang berantai dan apabila tidak diselesaikan akan menimbulkan dampak yang lebih luas lagi.Tidak hanya dalam kelangsungan usaha dan segi-segi ekonomi pada umumnya, tetapi juga kepada masalah ketenagakerjaan dan aspek sosial yang perlu diselesaikan

\footnotetext{
${ }^{1}$ Victorianus M.H. Randa Puang.2011.Penerapan Asas Pembuktian Sederhana dalam Penjatuhan Putusan Pailit, PT.Sarana Tutorial Nurani Sejahtera (SATU NUSA), Jakarta, hlm.1.
}

dengan adil dalam arti memperhatikan kepentingan pengusaha sebagai debitor ataupun kepentingan kreditor secara seimbang.

Sebagai contoh, ketika Direktur Utama Yamaichi Securities pada tanggal 1 Desember 1995 mengumumkan kebangkrutan perusahaannya pada suatu konfrensi pers di Tokyo,Jepang. Dari kasus ini dapat dilihat banyak pihak yang jadi korban apabila perusahaan dinyatakan pailit. Oleh karena itu lembaga kepailitan merupakan salah satu kebutuhan pokok di dalam aktivitas bisnis karena adanya status pailit. ${ }^{2}$ Untuk mengantisipasi adanya perbuatanperbuatan debitor yang merugikan kreditor,maka pemerintah melakukan perubahan-perubahan yang cukup signifikan dalam peraturan perundangundangan, salah satunya adalah dengan merevisi Undang-Undang Kepailitan yang ada.Sebelum Undang-Undang Nomor 4 Tahun 1998 jo Peraturan Pemerintah Pengganti Undang-Undang Nomor 1 Tahun 1998 dikeluarkan, masalah kepailitan dan penundaan kewajiban pembayaran utang di negara kita diatur dalam Faillisement Verordening (Staasblad Tahun 1905 Nomor 207 jo. Staatsblad Tahun 1906 Nomor 348). Dalam perjalanan waktunya Undang-Undang Nomor 4 Tahun 1998 dirasakan belum mampu mengakomodir semua kepentingan pihak-pihak dalam menyelesaikan masalah utang piutang. Oleh karena itu perlu dibenahi,disempurnakan baik dari

\footnotetext{
2 Sri Redjeki Hartini.2008.Hukum Kepailitan, Universitas Muhamadiyah Malang Press, Malang, hlm.3
}

Volume 17 Nomor 2. Bulan Mei 2019 
Serlika Aprita, Wewenang Dan Tanggung Jawab Hukum Kurator Atas Kesalahan Atau Kelalaiannya Mengakibatkan Kerugian Bagi Debitor Dalam Proses Hukum Pengurusan Dan Pemberesan Harta Pailit, halaman 154-174

aspek formil maupun materielnya. Maka, pada tanggal 18 November 2004 disahkan Undang-Undang Nomor 37 Tahun 2004 tentang Kepailitan dan Penundaan Kewajiban Pembayaran Utang. ${ }^{3}$

Jika ditelusuri sejarah hukum tentang kepailitan, diketahui bahwa hukum tentang kepailitan itu sendiri sudah ada sejak zaman Romawi. Kata bangkrut yang di dalam bahasa inggris disebut bankrupt berasal dari undang-undang di Italia yang disebut banca rupta. Pada abad pertengahan di Eropa, terjadi praktik kebangkrutan yang dilakukan dengan menghancurkan bangku-bangku dari para bankir atau pedagang yang melarikan diri secara diam-diam dengan membawa harta kreditornya. ${ }^{4}$ Adapun di Venetia (Italia) pada waktu itu, dimana para pemberi pinjaman (bankir) saat itu yang banco (bangko) mereka yang tidak mampu lagi membayar utang atau gagal dalam usahanya, bangkut tersebut benar-benar telah patah dan hancur. ${ }^{5}$

Dari perkembangan sejarah hukum kepailitan dapat diklasifikasikan konsep dasar kepailitan adalah sebagai berikut:

a. Debt collection merupakan konsep pembalasan dari kreditor terhadap debitor pailit dengan menagih klaimnya terhadap debitor atau harta debitor;

${ }^{3}$ Ibid.,hlm.8.

${ }^{4}$ Rachmadi Usman.2004.Dimensi Hukum Kepailitan di Indonesia,Gramedia Pustaka Utama,Jakarta, hlm.1.

${ }^{5}$ Munir Fuady.2005.Hukum Pailit Dalam Teori dan Praktek, Edisi Revisi (Disesuaikan dengan Undangundang Nomor 37 Tahun 2004), PT.Citra Aditya Bakti, Bandung, hlm.2. b. Debt Forgiveness dimanifestasikan dalam bentuk asset exemption (beberapaharta debitor dikecualikan dalam budel pailit), relief from imprisonment (tidak dipenjara karena gagal membayar utang); moratorium (penundaan pembayaran untuk jangka waktu tertentu dan discharge of indebtedness (pembebasan debitor atau harta debitor untuk membayar utang pembayaran yang benar-benar tidak dapat dipenuhinya);

c. Debt adjustment merupakan hak distribusi dari para kreditor sebagai suatu grup dengan menerapkan prinsip pro rata distribution atau structrued prorata (pembagian berdasarkan kelas kreditor) serta reorganisasi atau Penundaan Kewajiban Pembayaran Utang (PKPU). ${ }^{6}$

Lembaga kepailitan pada dasarnya merupakan lembaga yang memberikan suatu solusi terhadap para pihak apabila debitur dalam keadaan berhenti membayar atau tidak mampu membayar. Lembaga kepailitan pada dasarnya mempunyai dua fungsi sekaligus, yaitu :

1. Kepailitan sebagai lembaga pemberi jaminan kepada kreditor bahwa debitor tidak akan berbuat curang,

6 Emmy Yuhassarie dan Tri Harnowo.2005. Pendahuluan:Pemikiran Kembali Hukum Kepailitan Indonesia dalam Emmy Yuhassarie dan Tri Harnowo (Tim Editor), Undang-Undang Kepailitan dan perkembangannya:Prosidings Rangkaian Lokakarta Terbatas dan Masalah-Masalah Kepailitan dan Wawasan Hukum Bisnis Lainnya,Cet.2,Pusat Pengkajian Hukum,2005, hlm.xix.

Volume 17 Nomor 2. Bulan Mei 2019 
Serlika Aprita, Wewenang Dan Tanggung Jawab Hukum Kurator Atas Kesalahan Atau Kelalaiannya Mengakibatkan Kerugian Bagi Debitor Dalam Proses Hukum Pengurusan Dan Pemberesan Harta Pailit, halaman 154-174

dan tetap bertanggung jawab terhadap semua utang-utangnya kepada semua kreditor.

2. Kepailitan sebagai lembaga yang juga memberi perlindungan kepada debitor terhadap kemungkinan eksekusi massal oleh kreditorkreditornya.

3. Melindungi para kreditor konkuren untuk memperoleh hak mereka sehubungan dengan berlakunya asas jaminan yang diatur dalam ketentuan Pasal 1131 KUHPerdata. ${ }^{7}$

Dengan diputuskannya seorang debitor menjadi debitor pailit oleh Pengadilan Niaga, maka akan menimbulkan adanya suatu akibat hukum yang secara teoritis diatur dalam Bagian Kedua UndangUndang Kepailitan Nomor 37 Tahun 2004 yang terdiri dari Pasal 19 sampai dengan Pasal 62. ${ }^{8}$ Satu diantaranya adalah akibat hukum kepailitan terhadap debitor pailit dan hartanya. Harta pailit adalah harta milik debitor yang dinyatakan pailit dengan berdasarkan kepada putusan pengadilan. ${ }^{9}$ Berdasarkan ketentuan Pasal 21 Undang-Undang Nomor 37 Tahun 2004 menyatakan bahwa kepailitan meliputi seluruh harta kekayaan debitor pada saat pernyataan pailit itu diputuskan beserta semua harta kekayaan yang diperoleh

\footnotetext{
${ }^{7}$ Agus Subroto, "Undang-Undang Kepailitan dan Perkembangan Hukum Kepailitan Menyongsong Era Pasar Bebas",Makalah disampaikan pada Diskusi Hukum "Konsistensi Undang-Undang Kepailitan dan Impilikasinya Terhadap Perkembangan Dunia Usaha Khususnya di Sumatera Selatan", Mahameru Room Swarna Dwipa Hotel, Palembang, 21 Mei 2005, hlm.9.

${ }^{8}$ Parwoto Wignjosumarto.2003.Hukum Kepailitan Selayang Pandang “ Himpunan Makalah”, PT. Tata Nusa, Jakarta, hlm.118

${ }^{9}$ Gunawan Widjaja.2004.Tanggung Jawab Direksi atas Kepailitan Perseroan, Rajawali Pers, Jakarta,hlm.94.
}

selama kepailitan itu.Ketentuan pasal ini menunjukkan bahwa dengan pernyataan pailit, debitor pailit demi hukum kehilangan hak untuk menguasai dan mengurus kekayaannya yang dimaksudkan kedalam kepailitan, terhitung sejak tanggal kepailitan itu. Sehubungan dengan hilangnya hak untuk menguasai dan mengurus kekayaan debitor maka kuratornya yang berperan terhadap kekayaan debitor seperti yang diatur dalam Pasal 69 ayat (1) UndangUndang Kepailitan Nomor 37 Tahun 2004, yang isinya menerangkan bahwa kuratornya yang berwenang melakukan pengurusan dan pembesaran harta pailit.Dengan demikian,debitor kehilangan hak menguasai harta yang masuk dalam kepailitan namun tidak kehilangan hak atas harta kekayaan yang berada di luar kepailitan. ${ }^{10}$ Pendapat lain dari Imran Nating, kendati telah ditegaskan bahwa dengan di jatuhkannya putusan pailit harta kekayaan debitor pailit akan terus di kuasai oleh kurator, namun tidak semua kekayaan debitor pailit diserahkan kepada kurator. ${ }^{11}$

Ada beberapa harta yang dengan tegas dikecualikan dari kepailitan, yaitu :

1) Alat perlengkapan tidur dan pakaian sehari- hari;

2) Alat perlengkapan dinas;

3) Alat perlengkapan kerja;

4) Persediaan makan untuk kira-kira satu bulan;

5) Gaji, upah, pensiun, uang jasa dan honorium;

6) Hak cipta;

\footnotetext{
${ }^{10}$ Fennieka Kristianto.2009.Kewenangan Menggugat Pailit dalam Perjanjian Kredit Sindikasi, Minerva Athena Pressindo, Jakarta,hlm.83.

${ }^{11}$ Imran Nating.2004.Peranan dan Tanggung Jawab Kurator dalam Pengurusan dan Pemberesan Harta Pailit, PT.Raja Grafindo Persada, Jakarta,hlm.145.
} 
Serlika Aprita, Wewenang Dan Tanggung Jawab Hukum Kurator Atas Kesalahan Atau Kelalaiannya Mengakibatkan Kerugian Bagi Debitor Dalam Proses Hukum Pengurusan Dan Pemberesan Harta Pailit, halaman 154-174

7) Sejumlah uang yang ditentukan oleh hakim pengawas untuk nafkahkan (debitor);

8) Sejumlah uang yang diterima dari pendapatan anak- anaknya. ${ }^{12}$

Pengecualian di atas mirip dengan ketentuan Pasal 22 Undang-Undang Kepailitan Nomor 37 Tahun 2004 yang isinya menyebutkan bahwa ketentuan sebagaimana dimaksud pada Pasal 21 tidak berlaku terhadap:

a. Benda,termasuk hewan yang benarbenar dibutuhkan oleh debitor sehubungan dengan pekerjaannya, perlengkapan,alat-alat medis yang di pergunakan untuk kesehatan,tempat tidur dan perlengkapannya yang dipergunakan oleh debitor dan keluarganya,dan bahan makanan untuk 30 (tiga puluh) hari bagi debitor dan keluarganya yang terdapat di tempat itu;

b. Segala sesuatu yang diperoleh debitor dan pekerjannya sendiri sebagai pengganjian dari suatu jabatan atau jasa,sebagai upah, pensiun, uang tunggu atau uang tunjangan, sejauh yang ditentukan oleh hakim pengawas;

c. Uang yang diberikan kepada debitor untuk memenuhi suatu kewajiban memberi nafkah menurut undangundang.

Meskipun dalam hal yang demikian, debitor tidak kehilangan kecakapannya untuk melakukan perbuatan hukum (volkomen handelingsbevoeg), perbuatanperbuatannya tidakmempunyai akibat hukum atas harta

\footnotetext{
${ }^{12}$ Annalisa Yahanan, Op.Cit., hlm.60.
}

kekayaannya yang termasuk dalam budel kepailitan. Artinya jika debitor melanggar hukum ketentuan ini maka perbuatannya tidak mengikat kekayaannya tersebut, kecuali perikatan yang bersangkutan mendatangkan keuntungan bagi budel pailit. ${ }^{13}$ Berdasarkan ketentuan ini menunjukkan bahwa kepailitan mengakibatkan terjadinya ketidakpastian hukum bagi kreditor dalam memperoleh pelunasan pembayaran piutang. Atas dasar ini, maka undang-undang kepailitan menetapkan pihak yang akan melakukan pengurusan dan pemberesan terhadap harta kekayaan debitor pailit melalui kurator. Berdasarkan ketentuan Pasal 67 dan Pasal 67A UndangUndang Nomor 37 Tahun 2004 menyatakan bahwa kurator adalah orang perseorangan atau persekutuan perdata yang memiliki keahlian khusus sebagaimana diperlukan untuk mengurus dan membereskan harta pailit dan telah terdaftar dalam Departemen Kehakiman dan Hak Asasi Manusia. Menurut S.Wojowasito sebagaimana dikutip dari Annalisa Yahanan, kurator diartikan sebagai: (a) orang yang ditunjuk untuk mengawasi barang bangkrut; (b) orang yang melaksanakan curatele;(c) anggota komisi pengawas universitas. Berdasarkan ketiga makna kurator sebagaimana ditegaskan oleh S. Wojowasito, makna yang lebih tepat digunakan

\footnotetext{
${ }^{13}$ R.Anton Suyatno.2012.Pemanfaatan Penundaan Kewajiban Pembayaran Utang Sebagai Upaya Mencegah Kepailitan, Kencana,Jakarta,hlm.48.
}

Volume 17 Nomor 2. Bulan Mei 2019 
dalam artian kurator adalah orang yang ditunjuk untuk mengawasi barang bangkrut. ${ }^{14}$

Kurator diangkat oleh Pengadilan Niaga bersamaan dengan permohonan pernyataan pailit. Dalam hal debitor atau kreditor yang memohonkan kepailitan tidak mengajukan usul pengangkatan kurator lain kepada pengadilan, maka Balai Harta Peninggalan bertindak selaku kurator. Kurator yang diangkat oleh Pengadilan harus independen dan tidak mempunyai benturan kepentingan baik dengan debitor maupun dengan kreditor. Menunrut undang-Undang Nomor 37 Tahun 2004, kurator yang bertugas untuk melakukan pengurusan dan pemberesan terhadap harta debitor pailit tidak dimonopoli oleh Balai Harta Peninggalan sebagai satusatunya kurator,melainkan juga dibuka kemungkinan bagi pihak lain untuk turut serta menjadi kurator bagi harta debitor pailit, dengan ketentuan yang menjadi pihak tersebut mempunyai kriteria sebagaimana dijelaskan dalam Pasal 70 ayat 2 Undang-Undang Nomor 37 Tahun 2004 yaitu:

a. Orang perseorangan yang berdomisili di Indonesia, yang memiliki keahlian khusus yang dibutuhkan dalam rangka mengurus atau membereskan harta pailit;

b. Terdaftar pada kementerian yang lingkup tugas dan tanggung jawabnya di

\footnotetext{
${ }^{14}$ Annalisa Yahanan,Op.Cit.,hlm.76.
}

bidang hukum dan peraturan perundangundangan (Menteri Hukum dan HAM). ${ }^{15}$

Sebelum berlakunya Peraturan Pemerintah Pengganti Undang-Undang (Perpu) Nomor 1 Tahun 1998 yang kemudian ditetapkan oleh Dewan Perwakilan Rakyat (DPR) menjadi Undang-Undang Nomor 4 Tahun 1998 yang menjadi kurator hanyalah Balai Harta Peninggalan saja. Tetapi dengan berlakunnya Undang-Undang Nomor 37 Tahun 2004 yang dapat bertindak sebagai kurator selain Balai Harta Peninggalan juga orang perseorangan yang diangkat oleh pengadilan untuk mengurus dan membereskan harta debitor pailit. $^{16}$

Dalam menjalankan tugasnya kurator tidak sekedar bagaimana menyelamatkan harta pailit yang berhasil dikumpulkan untuk kemudian dibagikan kepada para kreditor,tetapi sedapat mungkin bisa meningkatkan nilai harta pailit.Kurator juga dituntut untuk memiliki integritas yang berpedoman pada kebenaran dan keadilan serta keharusan untuk mentaati standar profesi dan etika. Hal ini untuk menghindari benturan kepentingan dengan debitor maupun kreditor. 17 Namun pada penerapannya kurator banyak melakukakan kesalahan dan kelalaiannya dalam menjalankan tugasnya,hal ini sebagaimana ditemukan dalam berbagai contoh kasus sebagai berikut:

\footnotetext{
${ }^{15}$ Gunawan Widjaja.2009.Resiko Hukum dan Bisnis Perusahaan Pailit,Forum Sahabat,Jakarta,hlm.88

${ }^{16}$ Bagus Irawan.2007.Aspek-Aspek Hukum Kepailitan, Perusahaan dan Asuransi, PT. Alumni, Bandung,hlm.67.

17 Adrian Sutedi.2009. Hukum Kepailitan, Ghalia Indonesia.,Jakarta,hlm.66.
}

Volume 17 Nomor 2. Bulan Mei 2019 
Serlika Aprita, Wewenang Dan Tanggung Jawab Hukum Kurator Atas Kesalahan Atau Kelalaiannya Mengakibatkan Kerugian Bagi Debitor Dalam Proses Hukum Pengurusan Dan Pemberesan Harta Pailit, halaman 154-174

1. Kasus Kesalahan/ Kelalaian Kurator dalam Pengurusan dan Pemberesan Harta Pailit PT. Asuransi Jiwa Manulife Indonesia (PT. AJMI)

PT. AJMI adalah suatu perusahaan yang didirikan oleh Manulife Financial Corporation (Manulife) dari Kanada dengan saham 51\%,Dharmala Sakti Sejahtera,TBK. Dengan saham 40 $\%$ dan International Finance Corporation (IFC) dengan saham sebesar 9\%. Permohonan kepailitan PT. AJMI diajukan oleh PT. Dharma Sakti Sejahtera.TBK (PT.DSS), dengan alasan tidak membayar deviden keuntungan perusahaan pada tahun 1998. Alasan PT.DSS mempailitkan PT.AJMI adalah dengan dinyatakan PT. AJMI pailit,segala sesuatu yang menyangkut pengurusan harta kekayaan sepenuhnya dilakukan oleh kurator. Akan tetapi PT. AJMI menuntut untuk meminta dilakukan penggantian kurator Kali Sutan yang melakukan pengurusan dan pemberesan hartanya sebagai debitor pailit. Adapun latar belakang PT. AJMI menuntut untuk dilakukan penggantian kurator dilatarbelakangi oleh: (1) Kurator Kali Sutan sudah bukan berkedudukan sebagai Asosiasi Kurator Indonesia (AKI). Hal ini sebagaimana SK.Menteri Kehakiman menyatakan bahwa izin praktek kurator dalam melakukan pengurusan dan pemberesan harta debitor pailit hanya berlaku apabila kurator yang bersangkutan masih aktif sebagai anggota kurator AKI;(2)Kurator Kali Sutan tidak bertindak independen hal ini dikarenakan kurator masih terlibat pada beberapa kepentingan, yang dibuktikan dengan Kali Sutan pernah melawan pihak PT. AJMI di Hongkong pada tahun 2001, hal ini menunjukkan bahwa kurator dalam menjalankan tugas pokoknya yaitu melakukan pengurusan dan pemberesan harta debitor pailit tidak bersifat independen. ${ }^{18}$

2. Kasus Kesalahan atau Kelalaian Kurator dalam Pengurusan dan Pemberesan Harta Pailit PT.Adam Air

Mantan karyawan Adam Air yang tergabung dalam Serikat Pekerja Independent Adam Air (FORSIKAD) mengajukan gugatan di Pengadilan Negeri Jakarta Pusat. Mereka menuntut hakim mengganti kurator dalam kasus pemailittan perusahan penerbangan tersebut.Adapun kurator yang bertugas melakukan pengurusan dan pemberesan terhadap harta Adam Air adalah Gunawan Wiryaatmaja dan Anthony Prawira.

Menurut mantan karyawan Adam Air menyatakan bahwa kinerja kedua kurator tertunjuk ini dinilai tidak mampu mengatasi permasalahan karyawan yaitu dalam memperoleh pesangon dan uang penggantian hak serta uang masa penghargaan kerja.Kedua kurator ini dinilai lambat dalam mengurusi sidang mempailitkan dan mencairkan aset perusahaan Adam Air, akibatnya pencairan hak sekitar 3000 karyawan terancam tidak

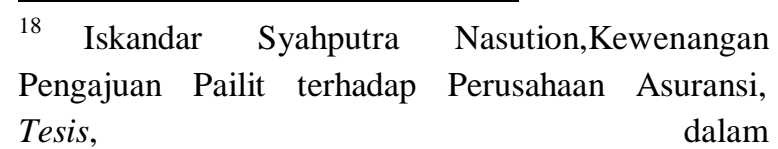
HYPERLINKhttp://www.scribd.com/doc/57254996/I SNANDAR-SYAHPUTRA-NASUTION" http: //www. scribd. com/d o c/57254996/ISNANDARSYAHPUTRA-NASUTION,diakses pada 2 Oktober 2012.

Volume 17 Nomor 2. Bulan Mei 2019 
Serlika Aprita, Wewenang Dan Tanggung Jawab Hukum Kurator Atas Kesalahan Atau Kelalaiannya Mengakibatkan Kerugian Bagi Debitor Dalam Proses Hukum Pengurusan Dan Pemberesan Harta Pailit, halaman 154-174

tuntas dan seharusnya hak karyawan yang mencapai Rp.120 M bisa segera cair pada Agustus 2008.Berdasarkan kasus ini menunjuukkan adanya kelalaian yang dilakukan oleh kurator dalam melakukan pengurusan dan pemberesan harta pailit sehingga mengakibatkan terjadinya kerugian bagi karyawan, kurator dianggap tidak mampu memperjuangkan hak karyawan. ${ }^{19}$

Berdasarkan kasus hukum diatas menunjukkan bahwa lembaga hukum kepailitan merupakan perangkat yang disediakan oleh hukum untuk menyelesaikan utang piutang diantara debitor dan kreditor dimana pengurusan dan pemberesan harta debitor pailit yang dilakukan oleh kurator belum dapat memberikan perlindungan hukum yang maksimal bagi pihak-pihak yang terlibat dalam proses hukum kepailitan khususnya bagi debitor dan kreditor. Keadaan ini berbanding terbalik dengan filosofi hukum kepailitan adalah untuk mengatasi permasalahan apabila seluruh harta kekayaan debitor tidak cukup untuk membayar seluruh utang-utangnya kepada kreditor dan kepailitan merupakan exit from financial distress yaitu suatu jalan keluar dari persoalan yang membelit secara finansial yang sudah tidak bisa diselesaikan lagi. Hal ini sebagaimana dijelaskan Mosgan Situmorang yang menyatakan bahwa tujuan utama kepailitan adalah untuk melakukan pembagian antara para kreditor atas kekayaan debitor oleh kurator. ${ }^{20}$ Kepailitan

${ }^{19}$ Eks Karyawan Adam Air Tuntut Hakim Ganti Kurator, dalam http://www. tempo.co/read /news/2009/ 01/12/083154829/Eks-Karyawan-AdamAir-Tuntut-Hakim-Ganti-Kurator,diakses pada 2 Oktober 2012.

${ }^{20}$ Mosgan Situmorang.1999.Tinjauan Atas UndangUndang Nomor 4 Tahun 1998 Tentang Penetapan Perpu Nomor 1 Tahun 1998 menjadi UndangUndang, Majalah Hukum Nasional Nomor 1, hlm. 163 . tersebut dimaksudkan untuk menghindari terjadinya sitaan terpisah atau eksekusi terpisah oleh kreditor dan menggantikannya dengan mengadakan sitaan bersama sehingga kekayaan debitor dapat dibagikan kepada semua kreditor sesuai dengan hak masing-masing karena kepailitan ada untuk menjamin para kreditor memperoleh hakhaknya atas harta debitor pailit.

Undang-undang kepailitan berbicara secara netral tentang kepailitan menyangkut debitor yang berada dalam keadaan berhenti membayar dan tidak membicarakan mengapa seseorang jatuh bangkrut dan juga tidak membedakan antara seorang pailit karena melakukan penipuan atau jatuh pailit diluar kesalahannya.Undang-undang kepailitan hanya mengatur bahwa pada saat ditagih orang tersebut dimana dalam hal ini debitor pailit yang tidak mampu membayar utangnya kepada kreditor-kreditornya dimana pengurusan dan pemberesan hartanya dikakukan oleh kurator.Hal ini sebagaimana diperkuat oleh pendapat Zainal Asikin menyatakan bahwa hukum kepailitan mempunyai fungsi yang sangat penting yaitu melalui hukum kepailitan akan diadakan suatu penyitaan umum (eksekusi massal) terhadap seluruh harta kekayaan debitor yang selanjutnya akan dibagikan kepada kreditor setelah terlebih dahulu dilakukan pengurusan dan pemberesan oleh kurator. ${ }^{21}$ Dengan demikian hukum kepailitan dibutuhkan sebagai alat collective proceeding, dalam rangka mengatasi collective action problem yang timbul dari kepentingan masing-masing kreditor. Artinya hukum kepailitan memberikan suatu mekanisme dimana para kreditor dapat bersama-sama menentukan apakah sebaiknya perusahaan atau harta kekayaan

21 Sunarmi,2010.Hukum

2,PT.Sofmedia,.Jakarta,hlm.20.

Kepailitan,Edisi

Volume 17 Nomor 2. Bulan Mei 2019 
Serlika Aprita, Wewenang Dan Tanggung Jawab Hukum Kurator Atas Kesalahan Atau Kelalaiannya Mengakibatkan Kerugian Bagi Debitor Dalam Proses Hukum Pengurusan Dan Pemberesan Harta Pailit, halaman 154-174

debitor diteruskan kelangsungan usahanya atau tidak, dan dapat memaksa kreditor minoritas mengikuti skim karena adanya prosedur pemungutan suara. $^{22}$

Kurator dalam melakukan pengurusan dan pemberesan terhadap harta debitor pailit pada prakteknya sering melakukan perbuatan-perbuatan curang dengan cara-cara yang mendekati tindak pidana sehingga mengakibatkan terjadinya kerugian bagi kreditor dikarenakan tidak terdapat kepastian hukum dalam memperoleh pelunasan piutang yang diperoleh dari harta debitor.Hal ini diperkuat dengan pendapat Kartini Muljadi yang menyatakan bahwa maksud dan tujuan dari Undang-Undang Kepailitan, yaitu untuk menghindari keadaan yang dapat merugikan kreditor. ${ }^{23}$ Selain itu ditinjau dari sudut sejarah hukum, undang-undang kepailitan bertujuan untuk melindungi para kreditor dengan memberikan jalan yang jelas dan pasti untuk menyelesaikan utang yang tidak dapat dibayar. $^{24}$

\section{B. Perumusan Masalah}

1. Bagaimanakah rasio hukum tanggung jawab hukum kurator yang atas kesalahan dan kelalaiannya mengakibatkan kerugian bagi debitor dalam proses hukum pengurusan dan pemberesan harta pailit?

\footnotetext{
${ }^{22}$ Daniel Suryana.2007.Hukum Kepailitan:Kepailitan terhadap Badan Usaha Asing oleh Pengadilan Niaga Indonesia,Pustaka Sutra, Bandung, hlm.37.

${ }^{23}$ Kartini Muljadi, Pengertian dan Prinsip-prinsip Umum Hukum Kepailitan, Rudhy A.Lontoh et,al, (ed), Op.Cit., hlm.75-76.

${ }^{24}$ Erman Rajagukguk, Latar Belakang dan Ruang Lingkup Undang-Undang Nomor 4 Tahun 1998 Tentang Kepailitan, Rudhy A.Lontoh et.al, (ed), Op.Cit., hlm.181.
}

2. Bagaimanakah bentuk dan mekanisme tanggung jawab hukum kurator yang atas kesalahan dan kelalaianya mengakibatkan kerugian bagi debitor dalam proses hukum pengurusan dan pemberesan harta pailit?

\section{Metode Penelitian}

- Tipe penelitian, tipe penelitiannya secara normatif yakni penelitian yang dilakukan berdasarkan peraturan perundang-undangan dengan meneliti bahan pustaka atau data sekunder. ${ }^{25}$ Pendekatan yang digunakan dalam penelitian ini adalah pendekatan perundang-undangan (statute approach), yaitu mengkaji normanorma yang terdapat dalam ketentuan perundang-undangan, dan dengan pendekatan konseptual (conceptual approach), yaitu mengkaji konsepkonsep yuridis yang berkaitan dengan implementasi peraturan perundangundangan hukum kepailitan dan penundaan kewajiban pembayaran utang.

- Data penelitian, dalam paper ini data berupa data sekunder yakni data yang diperoleh dari bahan pustaka baik yang bersifat pribadi maupun publik. ${ }^{26}$ Dari sudut kekuatan mengikatnya, data sekunder di golongkan ke dalam :

a. Bahan hukum primer; yang dipergunakan adalah peraturan perundang-undangan yang berkaitan peraturan perundang-undangan hukum kepailitan dan penundaan kewajiban pembayaran utang.

${ }^{25}$ Soerjono Soekanto, Pengantar Penelitian Hukum, Cetakan III, (Jakarta: UI-Press, 2008), hlm 52.

${ }^{26}$ Ibid. 
b. Bahan hukum sekunder; yang digunakan adalah buku-buku, makalah, ataupun artikel-artikel yang merupakan literatur hukum dan pendapat para sarjana di bidang hukum kepailitan dan penundaan kewajiban pembayaran utang.

- Prosedur Pengumpulan Bahan Hukum, bahan-bahan hukum primer dan sekunder yang didapat dan dikumpulkan berasal dari perpustakaan ataupun juga dari melakukan browsing di internet, yang selanjutnya bahanbahan tersebut dikelompokkan berdasarkan pokok permasalahan pada penelitian.

- Analisis Bahan Hukum, bahan-bahan hukum yang diperoleh tersebut dikelompokkan secara logis dan sistematis, untuk kemudian dilakukan analisa dengan mempergunakan metode deskriptif analitis dan ditafsirkan atau diinterpretasikan, sehingga nantinya akan diperoleh jawaban atas permasalahan dalam penelitian ini. Metode penelitian secara deskriptif adalah penelitian yang dilakukan dengan memberikan gambaran secara sistematis terhadap objek yang diteliti. Penelitian deskriptif ini dimaksudkan untuk memberikan data yang seteliti mungkin tentang manusia, keadaan, atau gejala-gejala yang lainnya. Maksudnya adalah untuk mempertegas hipotesa agar dapat membantu di dalam memperkuat teori-teori lama atau di dalam teori-teori baru. ${ }^{27}$

\section{PEMBAHASAN}

\section{A. Rasio Hukum Tanggung Jawab Hukum Kurator atas Kesalahan atau}

\footnotetext{
${ }^{27}$ Ibid, hlm 10.
}

Kelalaiannya mengakibatkan Kerugian bagi Debitor dalam Proses Hukum Pengurusan dan Pemberesan Harta Debitor Pailit

Kurator memiilki peranan penting dalam melakukan pengurusan dan pemberesan harta debitor pailit dengan cara memaksimalkan harta pailit sehingga kewajiban debitor kepada kreditor dapat terpenuhi.Oleh karena itu kreditor sangat mengharapkan kurator dapat melaksanakan tugasnya secara maksimal dengan harapan dapat memaksimalkan pengembalian aset (asset recovery).Namun pada praktiknya kurator dalam melaksanakan tugas pengurusan dan pemberesan ini banyak melakukan kesalahan dan kelalainan yang mengakibatkan kerugian bagi debitor yang mengharuskan kurator bertanggung jawab. Adapun rasio hukum tanggung jawab hukum kurator atas kesalahan dan kelalaiannya yang mengakibatkan kerugian bagi debitor dalam proses hukum pengurusan dan pemberesan harta debitor pailit sebagai berikut:

a. Kurator merupakan pihak yang melakukan pengurusan dan pemberesan harta debitor pailit dengan tata cara pengangkatan oleh Pengadilan Niaga

Ketentuan ini menjelaskan bahwa kurator telah diberikan kewajiban hukum oleh pengadilan niaga yang pengaturannya diatur dalam undangundang kepailitan yaitu untuk melakukan pengurusan dan pemberesan harta debitor pailit, dimana apabila ia melalaikan kewajiban ia harus bertanggung jawab atas kerugian yang timbul. Hal ini secara tegas dijelaskan dalam ketentuan Pasal 72 UndangUndang Nomor 37 Tahun 2004 menyatakan bahwa "kurator bertanggung jawab terhadap kesalahan/kelalaian dalam 
Serlika Aprita, Wewenang Dan Tanggung Jawab Hukum Kurator Atas Kesalahan Atau Kelalaiannya Mengakibatkan Kerugian Bagi Debitor Dalam Proses Hukum Pengurusan Dan Pemberesan Harta Pailit, halaman 154-174

melaksanakan tugas pengurusan
dan/atau pemberesan
mengakibatkan kerugian bagi harta
pailit".

Tanggung jawab hukum yang diberikan oleh pengadilan niaga bagi kurator harus dilaksanakan sebaikbaiknya. Hal ini dikarenakan kurator harus bertanggungjawab atas setiap perbuatan yang kesalahan atau kelalaian yang dapat merugikan harta debitor pailitdan kepentingan kreditor dalam memperoleh pelunasan piutang. Untuk menghindari perbuatan kurator supaya tidak berlaku sewenang-wenang atas kekuasaan yang dimilikinya,maka hukum membatasi kekuasaan tersbut dengan mengadakan sanksi.Esensi dari kekuasaan adalah hak untuk mengadakan sanksi. 28 Hal ini sebagaimana diperkuat oleh pendapat Peperzak yang mengemukakan adanya hubungan hukum dan kekuasaan satu diantaranya dengan cara menelaah konsep dari sanksi, yaitu apabila terdapat prilaku yang tidak mematuhi aturanaturan hukum menyebapkan diperlukan sanksi untuk penegakan aturan-aturan hukum tadi. Karena sanksi dalam kenyataannya merupakan suatu kekerasan, maka penggunaannya memerlukan legitimasi yuridis (pembenaran hukum) agar menjadikannya sebagai kekerasan yang sah. Agar sanksi dapat berfungsi dengan baik sehingga semua sistem hukum dapat bergaya guna serta berhasil, maka diperlukan adanya kekuasaan yang memberikan dukungan tenaga maupun perlindungan bagi sistem aturan hukum berikut dengan sanksi. ${ }^{29}$ Berdasarkan atas

\footnotetext{
${ }^{28}$ Miriam Budiardjo.2008.Dasar-Dasar Ilmu Politik, PT. Gramedia Pustaka Utama, Jakarta,hlm.61-62 ${ }^{29}$ Ibid
}

ketentuan ini apabila kurator tidak melaksanakan tanggung jawabnya dalam melakukan pengurusan dan pemberesan harta debitor pailit maka ia akan memperoleh sanksi.

b. Adanya ketidakpastian hukum bagi kreditor dalam memperoleh pelunasan piutang yang berasal dari harta debitor pailit yang pengurusan dan pemberesannya dilakukan oleh kurator

Dalam melaksanakan tugasnya melakukan pengurusan dan pemberesan terhadap harta debitor pailit kurator harus memaksimalkan nilai harta pailit sehingga dapat memberikan hasil optimal yang dipergunakan dalam melunasi utang-utang debitor.Tetapi,apabila kurator dalam melaksanakan tugasnya ini tidak melaksanakannya dengan maksimal maka akan mengakibatkan terjadinya ketidakpastian hukum bagi kreditorkreditor dalam memperoleh pelunasan piutang yang bersumber dari harta debitor pailit yang pengurusan dan pemberesannya dilakukan oleh kurator.

Langkah tepat yang dapat diambil oleh kreditor jika ada suatu rencana kebijakan atau perbuatan kurator yang tidak sesuai dengan kehendak kreditor diatur dalam ketentuan Pasal 77 ayat 1 Undang-Undang Nomor 37 Tahun 2004 menyatakan bahwa "setiap kreditor, panitia kreditor, dan panitia debitor pailit dapat mengajukan surat keberatan kepada Hakim Pengawas terhadap perbuatan yang dilakukan oleh kurator atau memohon kepada Hakim Pengawas untuk mengeluarkan surat perintah agar kurator melakukan perbuatan tertentu atau tidak melakukan perbuatan yang sudah direncanakan."Selanjutnya dalam 
Serlika Aprita, Wewenang Dan Tanggung Jawab Hukum Kurator Atas Kesalahan Atau Kelalaiannya Mengakibatkan Kerugian Bagi Debitor Dalam Proses Hukum Pengurusan Dan Pemberesan Harta Pailit, halaman 154-174

ketentuan Pasal 77 ayat 2 menyatakan bahwa"Hakim Pengawas harus menyampaikan surat keberatan kepada kurator paling lambat 3 (hari) setelah surat keberatan diterima." dan dalam Pasal 77 ayat 3 menyatakan bahwa "Kurator harus memberikan tanggapan kepada Hakim Pengawas paling lambat 3 (tiga) hari setelah menerima surat keberatan."

c. Adanya pengaturan dalam peraturan perundang-undangan mengenai tanggungjawab hukum kurator baik dalam kapasitas sebagai kurator dan pribadi dalam hal terjadinya kesalahan atau kelalaian dalam pengurusan dan pemberesan harta debitor pailit

Kurator dapat digugat dan wajib membayar ganti kerugian baik kapasitasnya sebagai kurator maupun pribadi apabila karena kelalaiannya dan kesalahannya (terdapat unsur kesengajaan) telah mengakibatkan kerugian bagi pihak-pihak yang berkepentingan dalam memperoleh pelunasan dari harta debitor pailit.

Dalam kapasitas tanggung jawab sebagai kurator sehubungan dengan kesalahan dan kelalaian yang mengakibatkan kerugian bagi harta debitor pailit telah diatur dalam ketentuan Pasal 77 Undang-Undang Nomor 37 Tahun 2004.

Dalam kapasitas tanggung jawab sebagai pribadi sehubungan dengan kesalahan dan kelalaian yang mengakibatkan kerugian bagi harta debitor pailit telah diatur dalam ketentuan Pasal 72 Undang-Undang Nomor 37 Tahun 2004. Kurator juga harus bertanggung jawab atas kesalahan dan kelalaian dalam melakaukan kewajiban pengurusan dan/atau pemberesan yang mengakibatkan kerusakan dan berkurangnya nilai harta pailit. Berdasarkan ketentuan Pasal 1365 KUHPerdata mengenai perbuatan melawan hukum,kurator dapat digugat untuk bertanggung jawab secara pribadi oleh pihak-pihak yang dirugikan atas sikap dan perbuatan kurator. Bahkan kurator harus bertanggungjawab secara pidana atas sikap dan perbuatannya itu.

d. Adanya penyalahgunaan wewenang yang diberikan oleh undang-undang kepailitan kepada kurator sehingga mengakibatkan kerugian bagi debitor

Secara umum kurator mempunyai kekuatan yuridis atau wewenang untuk melaksanakan proses pengurusan dan pemberesan harta debitor pailit.Pada penerapannya kurator sering melakukan penyalahgunaan wewenangnya yang mengakibatkan kerugian bagi harta debitor pailit.

Tindakan hukum kurator yang dianggap debitor merugikan harta pailitnya maka debitor pailit diperbolehkan mengajukan surat permohonan mengajukan perlawanan yang ditunjukkan kepada hakim pengawas terhadap setiap perbuatan yang dilakukan oleh kurator yang dianggap merugikan debitor pailit.

B. Bentuk dan Mekanisme Tanggung Jawab Hukum Kurator yang atas Kesalahan atau Kelalaianya mengakibatkan Kerugian bagi Debitor dalam Proses Hukum Pengurusan dan Pemberesan Harta Pailit
A.Tanggung Jawab Hukum Kurator dalam Kapasitas sebagai Kurator atas Kesalahan dan Kelalaiannya Selama Proses Pengurusan dan Pemberesan Harta Debitor Pailit 
Serlika Aprita, Wewenang Dan Tanggung Jawab Hukum Kurator Atas Kesalahan Atau Kelalaiannya Mengakibatkan Kerugian Bagi Debitor Dalam Proses Hukum Pengurusan Dan Pemberesan Harta Pailit, halaman 154-174

Kurator bertanggung jawab atas kesalahan dan kelalaiannya dalam melaksanakan tugas pengurusan dan pemberesan harta debitor pailit sebagaimana dijelaskan dalam Pasal 69 ayat 1 UndangUndang Nomor 37 Tahun 2004.Tanggung jawab kurator dalam kapasitas sebagai kurator dibebankan kepada harta pailit,danbukan kepada kurator secara pribadi yang harus membayar kerugian. Pihak yang menuntut mempunyai tagihan atas harta kepailitan dan tagihannya seperti utang harta pailit, seperti:

a) Kurator lupa memasukkan salah satu kreditor dalam rencana distribusi;

b) Kurator menjual aset debitor yang tidak masuk kedalam harta kepailitan;

c) Kurator menjual aset pihak ketiga;

d) Kurator berupaya menagih tagihan debitor yang pailit dan melakukan sita atas properti debitor, kemudian terbukti bahwa tuntutan debitor tersebut palsu. ${ }^{30}$

Mekanisme tanggung jawab hukum kurator dalam kapasitas sebagai kurator apabila terjadi suatu kesalahan dan kelalaian yang dilakukan oleh kurator selama proses pengurusan dan pemberesan harta debitor pailit, maka langkah yang dapat diambil oleh kreditor jika ada suatu rencana kebijakan atau perbuatan kurator yang tidak sesuai dengan kehendak kreditor sebagaimana dijelaskan dalam Pasal 77 ayat 1 Undang-Undang Nomor 37 Tahun 2004 menyatakan bahwa"Setiap kreditor, panitia kreditor, dan debitor pailit dapat

\footnotetext{
${ }^{30}$ Imran Nating,Op.Cit.,hlm. 116-117.
}

mengajukan surat keberatan kepada hakim pengawas untuk mengeluarkan surat perintah agar kurator melakukan perbuatan tertentu atau tidak melakukan perbuatan yang sudah direncanakan."Selanjutnya hakim pengawas menurut Pasal 77 ayat 2 Undang-Undang Nomor 37 Tahun 2004, harus menyampaikan surat keberatan tersebut kepada kurator paling lambat 3 hari setelah surat keberatan diterimanya. Adapun kurator harus memberikan tanggapan kepada hakim pengawas atas surat keberatan tersebut paling lambat 3 hari setelah surat keberatan tersebut diterimanya sebagaimana diatur dalam Pasal 77 ayat 3 UndangUndang Nomor 37 Tahun 2004. Setelah itu, berdasarkan Pasal 77 ayat 4 UndangUndang Nomor 37 Tahun 2004, hakim pengawas harus memberikan penetapan paling lambat 3 hari setelah tanggapan dari kurator sudah diterima oleh hakim pengawas

\section{B. Tanggung Jawab Hukum Kurator dalam Kapasitas sebagai Pribadi atas Kesalahan dan Kelalaiannya Selama Proses Pengurusan dan Pemberesan Harta Debitor Pailit}

Kurator bertanggung jawab terhadap kesalahan dan kelalaiannya dalam melaksanakan tugas pengurusan dan pemberesan harta debitor pailit yang mengakibatkan kerugian terhadap harta pailit sebagaimana tercantum dalam ketentuan Pasal 69 ayat 1 Undang-Undang Nomor 37 Tahun 2004.Setiap perbuatan kurator yang merugikan terhadap harta pailit ataupun dalam arti merugikan kepentingan kreditor, baik secara disengaja maupun tidak disengaja oleh kurator maka kurator harus dapat mempertanggungjawabkan perbuatannya tersebut. Hal ini secara tegas dinyatakan dalam Pasal 72 Undang-Undang Nomor 37 Tahun 2004 menyatakan bahwa: 
Serlika Aprita, Wewenang Dan Tanggung Jawab Hukum Kurator Atas Kesalahan Atau Kelalaiannya Mengakibatkan Kerugian Bagi Debitor Dalam Proses Hukum Pengurusan Dan Pemberesan Harta Pailit, halaman 154-174

Kurator bertanggung jawab terhadap kesalahan/kelalaian dalam metaksanalcan tugas pengurusan dan/atau pemberesan yang menyebabkan kerugian terhadap harta pailit.

Ini berarti kurator dalam melakukan pengurusan dan pemberesan tidak dapat bertindak sewenang-wenang, karena apabila ada perbuatan kurator yang merugikan harta pailit, maka harta pribadi kurator turut bertanggung jawab atas perbuatan tersebut.

Mengenai tanggung jawab hukum kurator dalam Undang-Undang Kepailitan, Jerry Hoff berpendapat:

In my opinion, this article doesn't create a stricter liablity than would arise under the applicable rule for tort (article 1365 CC). A receiver maybe held liable if he hascommited a tort. Any degree of gaultis sufficient to create liablity. The acts of receiver will presumably be compared withthe acts a reasonably competent receiver. It maybe argued,however, that the liabilty of a receiver must to be judged by a higher standards if he has more than everage expertise or experience.

M.Hadi Subhan menyatakan kurang sependapat mengenai pendapat Hoff bahwa ketentuan ketentuan tanggung jawab kurator dalam undang-undang kurang berarti karena sudah tersurat dalam Pasal 1365 KUHPerdata serta lebih mempercayai kemampuan kurator karena keahlian dan pengalamannya karena walaupun ketentuan mengenai tanggung jawab kurator telah diatur dalam dalam Pasal 1365 KUHPerdata yang bisa dianggap ketentuan overbodig, namun demikian saya berpendapat bahwa perlu ada penegasan spesifik dalam ketentuan kepailitan mengenai pertanggung jawaban kurator karena wewenang kurator yang sedemikian luasnya memerlukan rambu-rambu hukum yang pasti serta menghindarkan interpretasi yang meluas serta mengingat cakupan norma yang ada dalam Pasal1365 KUPerdata telrlalu fleksibel. Disamping itu juga dalam praktiknya tidak sedikit kurator yang menyalahgunakan kekuasaannya sebagai kurator, seperti yang terjadi dalam kasus kepailitan PT Indomas Pratama Putra. ${ }^{31}$

Tolak ukur untuk menentukan bahwa kurator telah melakukan kesalahan atau kelalaian dalam menjalankan tugas dan kewenangannya sebagaimana dimaksud dalam Pasal 72 Undang-Undang Nomor 37 Tahun 2004 menyatakan bahwa kurator mempunyai dua kewajiban hukum dalam melaksanakan tugas dan kewenangannya yaitu:

1. kewajiban yang pertama adalah sebagaimana ditentukan di dalam Undang-Undang Nomor 37 Tahun 2004, dengan kata lain, kurator mengemban statutory duties, yaitu kewajibankewajiban yang ditentukan oleh undangundang, dan

2. kewajiban kedua berupa fiduciary duties atau fiduciary obligations, dimana kurator mengemban fiduciary duties atau fiduciary obligations adalah karena kurator memiliki fiduciary relationship, Fiduciary duties kurator adalah terhadap:
a. Pengadilan; dalam UU Kepailitan Indonesia diwakili oleh hakim pengawas;
b. Debitor pailit;
c. Para kreditor;

\footnotetext{
${ }^{31}$ M.Hadi Subhan,Op.Cit.,hlm. 104.
} 
Serlika Aprita, Wewenang Dan Tanggung Jawab Hukum Kurator Atas Kesalahan Atau Kelalaiannya Mengakibatkan Kerugian Bagi Debitor Dalam Proses Hukum Pengurusan Dan Pemberesan Harta Pailit, halaman 154-174

d. Para pemegang saham.

Dengan kata lain, kurator mengemban kepercayaan dan pengadilan, debitor, para kreditor, dan para pemegang saham untuk melaksanakan tugasnya dengan sebaik-baiknya demi kepentingan pihakpihak tersebut. $^{32}$

Dalam ketentuan Pasal 78 ayat 1 Undang-Undang Nomor 37 Tahun 2004 menentukan apabila untuk melakukan perbuatan terhadap pihak ketiga, kurator memerlukan kuasa atau izin dari hakim pengawas tetapi temyata kuasa atau izin tersebut tidak ada atau tidak diperoleh atau kurator dalam melakukan perbuatan tersebut tidak mengindahkan ketentuan Pasal 83 dan Pasal 84 Undang-Undang Nomor 37 Tahun 2004, perbuatan terhadap pihak ketiga tersebut secara hukum adalah sah. Namun konsekuensinya, menurut Pasal 78 ayat 2 Undang-Undang Nomor 37 Tahun 2004 kurator harus bertanggung jawab sendiri secara pribadi terhadap debitor pailit dan kreditor.

Sebagai konsekuensi ketentuan Pasal 72 dan Pasal 78, kurator dapat digugat dan wajib membayar ganti kerugian apabila karena kelalaiannya, lebih-lebih lagi karena kesalahannya (dilakukan dengan sengaja) telah menyebabkan pihak-pihak yang berkepentingan terhadap harta pailit, terutama tentunya adalah para kreditor konkuren yang dirugikan yang mana kerugian itu terutama apabila harta pailit berkurangnya sehingga dengan demikian para kreditor konkuren memperoleh nilai pelunasan tagihannya kurang dan yang

${ }^{32}$ Sutan Remy Sjahdeini.2002.Hukum Kepailitan "Memahami Undang-Undang No. 37 Tahun 2004 tentang Kepailitan,PT.Pustaka Utama Grafiti, Jakarta,hlm.228. seharusnya diterima dan basil penjualan harta pailit sebagai akibat perbuatan kurator.

Wujud tanggung jawab hukum kurator atas kerugian yang ditimbulkan sebagai akibat dari kesalahan dan kelalaian kurator atas tindakan yang dilakukan oleh kurator tanpa adanya persetujuan dari hakim pengawas, dalam hal ini kurator bertanggung jawab secara pribadi dan kurator harus membayar sendiri kerugian yang ditimbulkannya, dimana tanggung jawab ini dapat terjadi, misalnya, jika kurator menggelapkan harta kepailitan dan segala kerugian yang timbul, sebagai akibat dari kelalaian atau karena ketidakprofesionalan kurator menjadi tanggung jawab kurator, oleh karenanya kerugian tersebut tidak bisa dibebankan pada harta pailit. Untuk menghadap di muka pengadilan, kurator harus terlebih dahulu mendapatkan izin dari hakim pengawas, kecuali menyangkut:

a. Sengketa pencocokkan piutang;atau

b. Sengketa tentang kepastian kelanjutan pelaksanaan perjanjian timbal balik yang belum atau baru sebagian dipenuhi (Pasal 36 UndangUndang Nomor 37 Tahun 2004); dan

c. Sengketa tentang penghentian hubungan sewa yang dilakukan oleh debitor pailit dengan pihak lain (Pasal 38 Undang-Undang Nomor 37 Tahun 2004). ${ }^{33}$

\footnotetext{
${ }^{33}$ Bernadette Waluyo.1999. Hukum Kepailitan dan Penundaan Kewajiban Pembayaran Utang, CV. Mandar Maju, Bandung,hlm.11.
} 
Serlika Aprita, Wewenang Dan Tanggung Jawab Hukum Kurator Atas Kesalahan Atau Kelalaiannya Mengakibatkan Kerugian Bagi Debitor Dalam Proses Hukum Pengurusan Dan Pemberesan Harta Pailit, halaman 154-174

Bentuk pertanggung jawaban hukum kurator lainnya atas kesalahan ataupun kelalaian dalam melakukan kewajiban pengurusan dan/atau penyelesaian yang menyebabkan kerusakan atau berkurangnya nilai harta pailit sebagaimana tercantum dalam ketentuan Pasal 74 ayat 1 UndangUndang Nomor 37 Tahun 2004 menyatakan bahwa "kurator harus menyampaikan laporan kepada hakim pengawas mengenai keadaan harta pailit dan pelaksanaan tugasnya setiap 3 (tiga)bulan." Selanjutnya laporan yang disampaikan oleh kurator ini bersifat terbuka untuk umum dan dapat dilihat setiap orang secara cuma-cuma ketentuan ini secara tegas dijelaskan dalamPasal 74 ayat 2 Undang-Undang Nomor 37 Tahun 2004.

Mengenai bentuk tanggung jawab hukum kurator dijelaskan juga dalam ketentuan Pasal 1365 KUH Perdata mengenai perbuatan melawan hukum, kurator dapat digugat untuk bertanggung jawab secara pribadi terhadap pihak-pihak yang dirugikan atas sikap dan perbuatan kurator.Bahkan kurator harus bertanggung jawab secara pidana atas sikap dan perbuatannya itu. Ketentuan ini mencakup dalam tindakan kurator yang merugikan harta pailit dan pihak ketiga tersebut merupakan tindakan di luar kewenangan kurator yang diberikan padanya oleh undang-undang kepailitan, tidak dapat dibebankan pada harta pailit, dan merupakan tangggung jawab kurator secara pribadi.

\section{PENUTUP \\ Kesimpulan}

1. Rasio hukum tanggung jawab hukum kurator yang atas kesalahan atau kelalaiannya mengakibatkan kerugian bagi debitor dalam proses hukum pengurusan dan pemberesan harta pailit adalah sebagai berikut:

a. Kurator merupakan pihak yang melakukan pengurusan dan pemberesan harta debitor pailit dengan tata cara pengangkatan oleh Pengadilan Niaga

Ketentuan ini menjelaskan bahwa kurator telah diberikan kewajiban hukum oleh pengadilan niaga yang pengaturannya diatur dalam undang-undang kepailitan yaitu untuk melakukan pengurusan dan pemberesan harta debitor pailit, dimana apabila ia melalaikan kewajiban ia harus bertanggung jawab atas kerugiandijelaskan dalam ketentuan Pasal 72 Undang-Undang Nomor 37 Tahun 2004 menyatakan bahwa "kurator bertanggung jawab terhadap kesalahan/kelalaian dalam melaksanakan tugas pengurusan dan/atau pemberesan yang mengakibatkan kerugian bagi harta pailit".

b. Adanya ketidakpastian hukum bagi kreditor dalam memperoleh pelunasan piutang yang berasal dari harta debitor pailit yang pengurusan dan pemberesannya dilakukan oleh kurator

Apabila kurator dalam melaksanakan tugasnya ini tidak maksimal maka akan mengakibatkan terjadinya ketidakpastian hukum bagi kreditor-kreditor dalam memperoleh pelunasan piutang yang bersumber dari harta debitor pailit yang pengurusan dan pemberesannya dilakukan oleh kurator. Langkah tepat yang dapat diambil oleh kreditor jika ada suatu rencana 
kebijakan atau perbuatan kurator yang tidak sesuai dengan kehendak kreditor diatur dalam ketentuan Pasal 77 ayat 1 Undang-Undang Nomor 37 Tahun 2004 menyatakan bahwa "setiap kreditor, panitia kreditor, dan panitia debitor pailit dapat mengajukan surat keberatan kepada Hakim Pengawas terhadap perbuatan yang dilakukan oleh kurator atau memohon kepada Hakim Pengawas untuk mengeluarkan surat perintah agar kurator melakukan perbuatan tertentu atau tidak melakukan perbuatan yang sudah direncanakan."

c. Adanya pengaturan dalam peraturan perundang-undangan mengenai tanggungjawab hukum kurator baik dalam kapasitas sebagai kurator dan pribadi dalam hal terjadinya kesalahan atau kelalaian dalam pengurusan dan pemberesan harta debitor pailit

Kurator dapat digugat dan wajib membayar ganti kerugian baik kapasitasnya sebagai kurator maupun pribadi apabila karena kelalaiannya dan kesalahannya (terdapat unsur kesengajaan) telah mengakibatkan kerugian bagi pihak-pihak yang berkepentingan dalam memperoleh pelunasan dari harta debitor pailit.

Dalam kapasitas tanggung jawab sebagai kurator sehubungan dengan kesalahan dan kelalaian yang mengakibatkan kerugian bagi harta debitor pailit telah diatur dalam ketentuan Pasal 77 Undang-Undang Nomor 37 Tahun 2004.

Dalam kapasitas tanggung jawab sebagai pribadi sehubungan dengan kesalahan dan kelalaian yang mengakibatkan kerugian bagi harta debitor pailit telah diatur dalam ketentuan Pasal 72 Undang-Undang Nomor 37 Tahun 2004. Kurator juga harus bertanggung jawab atas kesalahan dan kelalaian dalam melakaukan kewajiban pengurusan dan/atau pemberesan yang mengakibatkan kerusakan dan berkurangnya nilai harta pailit. Berdasarkan ketentuan Pasal 1365 KUHPerdata mengenai perbuatan melawan hukum,kurator dapat digugat untuk bertanggung jawab secara pribadi oleh pihak-pihak yang dirugikan atas sikap dan perbuatan kurator. Bahkan kurator harus bertanggungjawab secara pidana atas sikap dan perbuatannya itu.

d. Adanya penyalahgunaan wewenang yang diberikan undang-undang kepailitan kepada kurator sehingga mengakibatkan kerugian bagi debitor Pada penerapannya kurator sering melakukan penyalahgunaan wewenangnya yang mengakibatkan kerugian bagi harta debitor pailit.Tindakan hukum kurator yang dianggap debitor merugikan harta pailitnya maka debitor pailit diperbolehkan mengajukan surat permohonan mengajukan perlawanan yang ditunjukkan kepada hakim pengawas terhadap setiap perbuatan yang dilakukan oleh kurator yang dianggap merugikan debitor pailit.

2. Bentuk dan mekanisme tanggungjawab hukum kurator yang atas kesalahan atau kelalaiannya mengakibatkan kerugian bagi debitor dalam proses hukum pengurusan dan pemberesan harta pailit dapat dibagi menjadi 2 (dua), yaitu:

a. Tanggung Jawab Hukum Kurator dalam Kapasitas sebagai Kurator 
Serlika Aprita, Wewenang Dan Tanggung Jawab Hukum Kurator Atas Kesalahan Atau Kelalaiannya Mengakibatkan Kerugian Bagi Debitor Dalam Proses Hukum Pengurusan Dan Pemberesan Harta Pailit, halaman 154-174

Tanggung jawab kurator dalam kapasitas sebagai kurator dibebankan kepada harta pailit,dan bukan kepada kurator secara pribadi yang harus membayar kerugian. Pihak yang menuntut mempunyai tagihan atas harta kepailitan dan tagihannya seperti utang harta pailit, seperti:

a) Kurator lupa memasukkan salah satu kreditor dalam rencana distribusi;

b) Kurator menjual aset debitor yang tidak masuk kedalam harta kepailitan;

c) Kurator menjual aset pihak ketiga;

d) Kurator berupaya menagih tagihan debitor yang pailit dan melakukan sita atas properti debitor, kemudian terbukti bahwa tuntutan debitor tersebut palsu.

Mekanisme tanggung
jawab hukum kurator dalam
kapasitas sebagai kutator apabila
terjadi suatu kesalahan atau
kelalaian yang dilakukan oleh
kurator selama proses
pengurusan dan pemberesan
harta debitor pailit, maka langkah
yang dapat diambil oleh kreditor
jika ada suatu rencana kebijakan
atau perbuatan kurator yang tidak
sesuai dengan kehendak kreditor
sebagaimana dijelaskan dalam
Pasal 77 ayat 1 Undang-Undang
Nomor 37 Tahun 2004
menyatakan bahw"Setiap
kreditor, panitia kreditor, dan
debitor pailit dapat mengajukan
surat keberatan kepada hakim

pengawas untuk mengeluarkan surat perintah agar kurator melakukan perbuatan tertentu atau tidak melakukan perbuatan yang sudah direncanakan."

\section{b. Tanggung Jawab Hukum Kurator dalam Kapasitas Pribadi}

Setiap perbuatan kurator yang merugikan terhadap harta pailit ataupun dalam arti merugikan kepentingan kreditor, baik secara disengaja maupun tidak disengaja oleh kurator maka kurator harus dapat mempertanggungjawabkan perbuatannya tersebut. Hal ini secara tegas dinyatakan dalam Pasal 72 Undang-Undang Nomor 37 Tahun 2004.

Wujud tanggung jawab hukum kurator atas kerugian yang ditimbulkan sebagai akibat dari kesalahan dan kelalaian kurator atas tindakan yang dilakukan oleh kurator tanpa adanya persetujuan dari hakim pengawas sebagaimana dijelaskan dalam Pasal 78 Undang-Undang Nomor 37 Tahun 2004, dalam hal ini kurator bertanggung jawab secara pribadi dan kurator harus membayar sendiri kerugian yang ditimbulkannya, dimana tanggung jawab ini dapat terjadi, misalnya, jika kurator menggelapkan harta kepailitan dan segala kerugian yang timbul, sebagai akibat dari kelalaian atau karena ketidakprofesionalan kurator menjadi tanggung jawab kurator, oleh karenanya kerugian tersebut tidak bisa dibebankan pada harta pailit.

Bentuk pertanggung jawaban hukum kurator lainnya sebagaimana tercantum dalam ketentuan Pasal 74 ayat 1 UndangUndang Nomor 37 Tahun 2004 menyatakan bahwa "kurator harus menyampaikan laporan kepada hakim pengawas mengenai 
Serlika Aprita, Wewenang Dan Tanggung Jawab Hukum Kurator Atas Kesalahan Atau Kelalaiannya Mengakibatkan Kerugian Bagi Debitor Dalam Proses Hukum Pengurusan Dan Pemberesan Harta Pailit, halaman 154-174

keadaan harta pailit dan pelaksanaan tugasnya setiap 3 (tiga)bulan." Selanjutnya laporan yang disampaikan oleh kurator ini bersifat terbuka untuk umum dan dapat dilihat setiap orang secara cuma-cuma ketentuan ini secara tegas dijelaskan dalamPasal 74 ayat 2 Undang-Undang Nomor 37 Tahun 2004.

Mengenai bentuk tanggung jawab hukum kurator dijelaskan juga dalam ketentuan Pasal 1365 KUH Perdata mengenai perbuatan melawan hukum, kurator dapat digugat untuk bertanggung jawab secara pribadi terhadap pihak-pihak yang dirugikan atas sikap dan perbuatan kurator.Bahkan kurator harus bertanggung jawab secara pidana atas sikap dan perbuatannya itu.

\section{B. Saran}

1. Kurator hendaknya dalam menjalankan tugasnya dituntutuntuk memiliki integritas yang berpedoman kepada kebenaran dan keadilan serta keharusan untuk mentaati standar profesi dan kode etik yang berlaku. Hal ini sebagai upaya untuk menghindari terjadinya perbuatan itikad buruk debitor selama melaksanakan tugas pengurusan dan pemberesan harta debitor pailit.

2. Tanggung jawab hukum kurator terhadap adanya kesalahan atau kelalaian hendaknya berupa hukum pidana penjara dan denda maksimal dilakukan dengan cara reposisi atau amandemen Undang-Undang Nomor 37 Tahun 2004 khusus mengenai sanksi bagi kurator sebagai upaya penegakkan hukum dengan tujuan untuk memberikan efek jera bagi kurator untuk melakukan perbuatan melawan hukum. Selain itu kurator hendaknya dalam menjalankan tugas secara maksimal dalam upaya mencapai hasil optimal terhadap nilai harta pailit.
Ahmad Yani dan Gunawan Widjaja.2002.Seri Hukum Bisnis Kepailitan,PT. Raja Grafindo Persada, Jakarta.

Adrian Sutendi.2009.Hukum Kepailitan, Ghalia Indonesia,Bogor.

Annalisa Yahanan.2007.Kepailitan dan Penundaan Kewajiban Pembayaran Utang:Alternatif Penyelesaian Utang Piutang,UNSRI, Palembang.

Bagus Irawan.2007.Aspek-Aspek Hukum Kepailitan, Perusahaan dan Asuransi, PT. Alumni, Bandung.

Bernadette Waluyo.1999. Hukum Kepailitan dan Penundaan Kewajiban Pembayaran Utang, CV. Mandar Maju, Bandung.

Bagir Manan.2001.Mengenai PERPU Kepailitan, Rudhy A.Lontoh et.al, (ed), dalam Penyelesaian Utang Piutang Melalui Pailit atau Penundaan Kewajiban Pembayaran Utang, Alumni, Bandung.

Daniel Suryana.2007.Hukum Kepailitan:Kepailitan terhadap Badan Usaha Asing oleh Pengadilan Niaga Indonesia,Pustaka Sutra, Bandung, 2007.

Erman Rajagukguk, Latar Belakang dan Ruang Lingkup Undang-Undang Nomor 4 Tahun 1998 Tentang Kepailitan, Rudhy A.Lontoh et.al, (ed), Op.Cit..

Emmy Yuhassarie dan Tri Harnowo.2005.Pendahuluan:Pemikiran

Kembali Hukum Kepailitan indonesia dalam Emmy Yuhassarie dan Tri Harnowo (Tim Editor), Undang-Undang Kepailitan dan Perkembangannya:Prosidings Rangkaian Lokakarya Terbatas dan Masalah-Masalah Kepailitan dan Wawasan Hukum Bisnis

\section{DAFTAR PUSTAKA}


Serlika Aprita, Wewenang Dan Tanggung Jawab Hukum Kurator Atas Kesalahan Atau Kelalaiannya Mengakibatkan Kerugian Bagi Debitor Dalam Proses Hukum Pengurusan Dan Pemberesan Harta Pailit, halaman 154-174

Lainnya,cet.2. Pusat Pengkajian Hukum,Jakarta.

Fennieka Kristianto.2009.Kewenangan Menggugat Pailit dalam Perjanjian Kredit Sindikasi, Minerva Athena Pressindo, Jakarta.

Gunawan Widjaja.2004.Tanggung Jawab Direksi atas Kepailitan Perseroan, Rajawali Pers, Jakarta.

Gunawan Widjaja.2009.Resiko Hukum dan Bisnis Perusahaan Pailit, Forum Sahabat, Jakarta.

Imran Nating.2004. Peranan dan Tanggung Jawab Kurator dalam Pengurusan dan Pemberesan Harta Pailit, PT.Raja Grafindo Persada, Jakarta.

Jono.2008.Hukum Kepailitan,Sinar Grafika, Jakarta.

Kartini Muljadi dan Gunawan Widaja.2004.Pedoman Menangani Perkara Kepailitan, PT. Raja Grafindo Persada, Jakarta.

Kartini Muljadi, Pengertian dan PrinsipPrinsip Umum Hukum Kepailitan, Rudhy A. Lontoh et.al, (ed), Op.Cit.,.

Lili Rasyidi.1990. Dasar-Dasar Filsafat Hukum,Citra Aditya Bakti,Jakarta.

Munir Fuady.2010. Hukum Pailit dalam Teori dan Praktek, Edisi Kedua, PT. Citra Aditya Bakti, Bandung.

Man S. Sastrawidjaja.2010.Hukum Kepailitan dan Penundaan Kewajiban Pembayaran Utang, PT.Alumni, Bandung.

M.Hadi Subhan.2009. Hukum Kepailitan:Prinsip, Norma dan Praktik di Peradilan, Kencana, Jakarta.

Rahayu Hartini.2007. Hukum Kepailitan,Universitas Muhamadiyah Malang Press, Malang.

Rachmadi Usman.2004.Dimensi Hukum Kepailitan di Indonesia,Gramedia Pustaka Utama, Jakarta.

R.Anton Suyatno.2012.Pemanfaatan Penundaan Kewajiban Pembayaran Utang Sebagai Upaya Mencegah Kepailitan, Kencana,Jakarta.

Sunarmi.2010. Prinsip Keseimbangan dakan Hukum Kepailitan di Indonesia"A Critical Review on Bankruptcy Law: Towards The Bankruptcy Laws That Protect Creditor and Debitor Interest", Edisi 2, PT. Sofmedia, Jakarta.

Sutan Remy Sjahdeini.2002.Hukum Kepailitan "Memahami Undang-Undang No. 37 Tahun 2004 tentang Kepailitan, PT.Pustaka Utama Grafiti, Jakarta.

Sunarmi.2010.Hukum Kepailitan, Edisi 2, PT.Sofmedia, Jakarta.

Victorianus M.H. Randa Puang.2011.Penerapan Asas Pembuktian Sederhana dalam Penjatuhan Putusan Pailit, PT.Sarana Tutorial Nurani Sejahtera (SATU NUSA), Jakarta.

Zainal Asikin.2001.Hukum Kepailitan dan Penundaan Pembayaran di Indonesia, PT Raja Grafindo Persada, Jakarta.

Agus Subroto.2005 .Undang-Undang Kepailitan dan Perkembangan Hukum Kepailitan Menyongsong Era Pasar Bebas,Makalah disampaikan pada Diskusi Hukum "Konsistensi Undang-Undang Kepailitan dan Impilikasinya Terhadap Perkembangan Dunia Usaha Khususnya di Sumatera Selatan", Mahameru Room Swarna Dwipa Hotel, Palembang. 
Serlika Aprita, Wewenang Dan Tanggung Jawab Hukum Kurator Atas Kesalahan Atau Kelalaiannya Mengakibatkan Kerugian Bagi Debitor Dalam Proses Hukum Pengurusan Dan Pemberesan Harta Pailit, halaman 154-174

Dani K.2002. Kamus Lengkap Bahasa Indonesia, Putra Harsa, Surabaya.

Iskandar Syahputra Nasution,Kewenangan

Pengajuan Pailit terhadap Perusahaan Asuransi, Tesis, dalam HYPERLINKhttp://www.scribd.com/doc/57 254996/ISNANDAR-SYAHPUTRA-

NASUTION" http: //www. scribd. com/d o c/57254996/ISNANDAR-SYAHPUTRA-

NASUTION,diakses pada 2 Oktober 2012.

Kelik Pramudya,Pengadilan Niaga sebagai Lembaga Penyelesaian Perkara Kepailitan,Artikel, dalamhttp://clickgtg.blogspot.com/2009/02/pengadilan-niagasebagai-lembaga.html,diakses pada 2 Oktober 2012.

Mosgan Situmorang.1999.Tinjauan Atas Undang-Undang Nomor 4 Tahun 1998 Tentang Penetapan Perpu Nomor 1 Tahun 1998 menjadi Undang-Undang”, Majalah Hukum Nasional Nomor 1, Jakarta.

Eks Karyawan Adam Air Tuntut Hakim Ganti Kurator, dalam http://www. tempo.co/read /news/2009/ 01/12/083154829/Eks-Karyawan-AdamAir-Tuntut-Hakim-Ganti-Kurator,diakses pada 2 Oktober 2012.

Undang-Undang Nomor 37 Tahun 2004 tentang Kepailitan dan Penundaan Kewajiban Pembayaran Utang. 